\title{
Preferred display size and visual distance for ultrasound-guided radial artery cannulation
}

\section{Tamaño preferido de la imagen en pantall a y distancia visual para la canalización de la a rteria radiall guiada por ecografía}

\section{Takuo Hoshi}

Department of Anesthesiology and Critical Care Medicine, Ibaraki Clinical Education and Training Center, University of Tsukuba Hospital / Ibaraki Prefectural Central Hospital. Ibaraki, Japan.

Correspondence: 6528 Koibuchi, Kasama-city, Ibaraki prefecture, 309-1793. Ibaraki, Japan.

Email: 124stern@gmail.com

\begin{abstract}
What do we know about this topic?

- In-line positioning of an ultrasound image provides higher success rates and less time to completion for radial arterial cannulation.

- Preferable size and distance of ultrasound display is not widely discussed.
\end{abstract}

What new knowledge does this study contribute?

- About half (53\%) of the anesthesiologist interviewed in Japan preferred the smaller display (4- or 5.5-inch) fixed at a distance of 30 to $40 \mathrm{~cm}$. The rest preferred the larger display (7.9- or 9.7-inch) placed posterior to the probe with a visual distance of 45 to $60 \mathrm{~cm}$.

- Preferences should be considered when building a new system with in line positioning layout.

\section{How to cite this article:}

Hoshi T. Preferred display size and visual distance for ultrasound-guided radial artery cannulation. Colombian Journal of Anesthesiology. 2021;49:e968.

\section{Abstract}

Introduction: In-line positioning of an ultrasound image provides higher success rates and less time to completion for radial arterial cannulation. But preferable size and distance of ultrasound display has not been previously discussed.

Objective: To assess the ideal visual distance and display size when using a smart phone or tablet as the ultrasound image display.

Methods: Four smart phones or tablets were used as ultrasound displays in six different configurations in a simulated radial artery puncture. In a questionnaire, 116 anaesthesiologists working in Ibaraki Prefecture, Japan, were asked which of the six configurations was preferable for radial artery cannulation.

Results: Sixty anaesthesiologists answered the questionnaire. About half (53\%) preferred the smaller display (4- or 5.5-inch) fixed at a distance of 30 to $40 \mathrm{~cm}$, and most of the rest (44\%) preferred the larger display (7.9- or 9.7-inch) placed posterior to the probe with a visual distance of 45 to $60 \mathrm{~cm}$.

Conclusions: Among the anaesthesiologists, the preferable size and visual distance for ultrasound-guided radial artery cannulation varied using a smart phone or tablet for in-line display.

Keywords: Ultrasound guidance; radial artery cannulation; visual distance; display size; In-line positioning. 


\section{Resumen}

\section{Introducción}

El posicionamiento en línea con una imagen ecográfica permite mayores tasas de éxito y reduce el tiempo para realizar la canalización de la arteria radial. Sin embargo, no se ha hablado sobre cuál es el tamaño y la distancia preferibles para la imagen en pantalla.

\section{Objetivo}

Evaluar la distancia visual y el tamaño de la imagen en pantalla cuando se utiliza un teléfono inteligente o una tableta para visualizar la imagen ecográfica.

\section{Métodos}

Se utilizaron cuatro teléfonos inteligentes o tabletas como pantalla para visualizar las imágenes ecográficas en seis configuraciones distintas, en una simulación de la canalización de la arteria radial. Mediante un cuestionario se preguntó a 116 anestesiólogos que trabajan para la Prefectura de Ibaraki, Japón, cuál de las seis configuraciones era preferible para la canalización de la arteria radial.

\section{Resultados}

Sesenta anestesiólogos respondieron el cuestionario. Aproximadamente la mitad (53\%) prefirieron la imagen más pequeña ( 405,5 pulgadas), fija a una distancia de 30 a $40 \mathrm{~cm}$, y la mayoría de los otros (44\%) prefirieron la imagen más grande (7,9- 0 9,7 pulgadas), colocada en la parte posterior al transductor, con una distancia visual de 45 a $60 \mathrm{~cm}$.

\section{Conclusiones}

Entre los anestesiólogos, el tamaño preferido y la distancia visual para la canalización de la arteria radial guiada por ecografía, varió utilizando un teléfono inteligente o una tableta para su visualización en línea.

\section{Palabras clave}

Guía por ecografía; canalización de la arteria radial; distancia visual; tamaño de la imagen en pantalla; posicionamiento en línea.

\section{INTRODUCTION}

Arterial cannulation is an important procedure performed in the operating room and intensive care unit to allow continuous blood pressure monitoring and repeated arterial blood sampling. The most common site for arterial cannulation is the radial artery because of its superficial location and relatively low rate of complications. However, sometimes complications such as arterial occlusion, pseudo-aneurysm, hematoma formation, and bleeding occur in radial artery cannulation, especially in difficult cases. (1) Recently, ultrasound-guided radial artery cannulation has become a common procedure, with a reportedly significant increase in first-attempt success rates. (2) The use of ultrasound, in-line layout of the equipment simplifies the procedure, and the success rate and time required for cannulation are improved compared to the conventional layout (3). Preferable size and distance of ultrasound display have not been previously discussed. Tsuchiya et al. (3) used a 20-cm ultrasound image display, with the needle puncture site and display in a straight line and a distance from the operator's eye to the display of about 60 $\mathrm{cm}$. However, the most appropriate size and position of the display are unknown. In this study, a questionnaire was used to reveal the ideal ultrasound display size and distance to the operator's eye to facilitate radial artery puncture by the anesthesiologist.

\section{METHODS}

Wireless ultrasound image display system. A wireless display system similar to that used by Tsuchiya et al. (3) was designed. The Sonosite Edge IITM and L25X 13-6 $\mathrm{MHz}$ probe (Fujifilm Sonosite Inc., WA, USA) ultrasound equipment was used. Ultrasound image output was acquired from the DVI video outlet of the mini-doc of Sonosite Edge IITM. Resolution of the ultrasound image was up-scaled by an HDMI scaler HTCP-298HWTM (Cypress Technology Co., New Taipei City, Taiwan) from $640 \times 480$ to $1280 \times 720$. After that, a wifi HDMI transmitter, Accsoon CineeyeTM (Accsoon, Chengdu, China) was connected. Six display configurations were prepared. First, a 4-inch display (iPhone 5S, Apple Japan LLC, Tokyo, Japan) was fixed to an ultrasound probe. Second, a 5.5-inch display (iPhone 6S, Apple Japan LLC, Tokyo, Japan) was also fixed to an ultrasound probe. The distance of both displays distances from 
FIGURA 1. Position of display and distance from operator's eye.

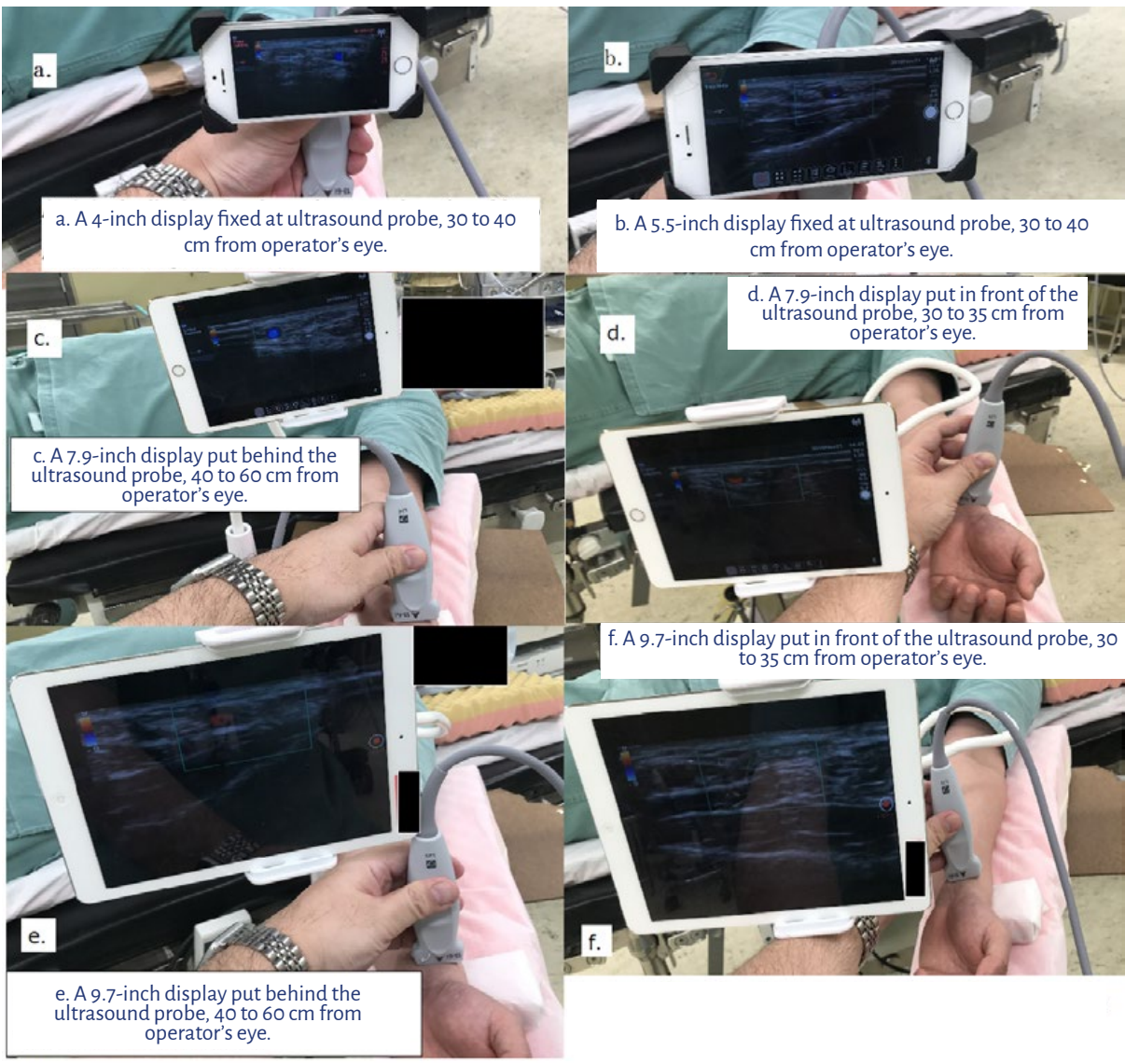

SOURCE: Authors.

the operator's eye were 30 to $40 \mathrm{~cm}$. Third, a 7.9-inch display (iPad mini, Apple Japan LLC, Tokyo, Japan) was placed on the front and back of the probe. Finally, a 9.7-inch display (iPad, Apple Japan LLC, Tokyo, Japan) was placed on the front and back of the probe. The distance from the operator's eye to the display placed on the front of the probe was 30 to $35 \mathrm{~cm}$, and to the display placed on the back of the probe was 40 to $60 \mathrm{~cm}$.

This study was conducted after receiving approval from the ethics committee of Ibaraki Prefectural Central Hospital (Res. Id. No. 793). No registration or informed consent was required since this was not considered a human clinical study.

Wireless ultrasound image display and probing were simulated using a demonstration patient (Figures 1a-f). Almost all anesthesiologists who are working in Ibaraki Prefecture, Japan, a shown in Figures 2, 3a, and $3 \mathrm{~b}$. In this study, $50 \%$ of the responders had more than 11 years of experience as anesthesiologists. In terms of in ultrasound-guided radial artery cannulation experience, 11 (18\%) had performed less than 10 cases and 19 (32\%) had performed more than 51 cases. However, most responders (90\%) had performed more than 51 ultrasound-guided nerve blocks. About half of respondents (53\%) preferred a smaller display (4- or 5.5-inch) fixed on the ultrasound probe, and most of the other respondents (44\%) preferred a larger display (7.9- or 9.7-inch) positioned at the back of the probe (Figure 4). Nobody favored the 9.7-inch display configuration in front of the probe.

\section{DISCUSSION}

In this questionnaire, the preferred size of the display varied. About half of the respondents preferred a small display (4or 5.5-inch), and about half preferred the tablet (larger display of 7.9 or 9.7 inches) behind the ultrasound probe.

When large wall-sized displays are used to read text, the display size does not affect individual performance if the visual angles are the same (4). The preferred distance for a large wall-sized display $(\mathrm{cm})$ is reported as $(2.73 \times$ diagonal screen size +75$) /$ diagonal screen size (5), but preferred distances for small displays such as smart phones and tablets are not reported. Visual distance using a smart phone for reading text is 33.7 $\mathrm{cm}$ for Japanese young adults and $35.6 \mathrm{~cm}$ foryoung adults in the United States $\underline{(6,7)}$. In this investigation, visual distances for small displays are about 35 to $45 \mathrm{~cm}$, and these distances are familiar for young doctors focusing on smart phones. The preferable visual distances for smart phones and tablets in middle-aged and elderly people are not known. Results may be affected by presbyopia. The anesthesiologists were asked about their levels of experience, but not about their ages; the influence of age is unknown. 
FIGURE 2. Level of experience of the anesthesiologists.

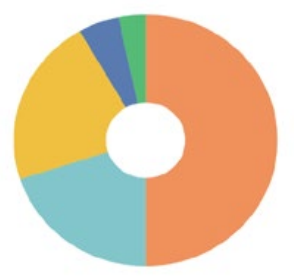

$0 \sim 1$ year

$1 \sim 2$ years

$3 \% \quad 2$

$3 \sim 5$ years

$5 \% \quad 3$

$6 \sim 10$ years

$22 \% \quad 13$

$20 \% \quad 12$

more than 11 years

$50 \% 30$

SOURCE: Authors.

FiguRE 3B. Experience with ultrasoundguided nerve blocks.

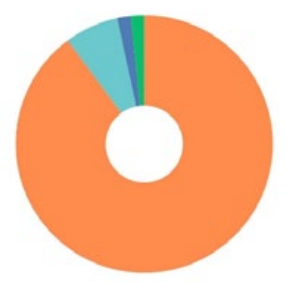

$\begin{array}{lll}\text { None } & 2 \% & 1 \\ \text { Less than } 10 \text { cases } & 2 \% & 1 \\ 11 \sim 20 \text { cases } & 0 \% & 0 \\ 21 \sim 50 \text { cases } & 7 \% & 4 \\ \text { More than } 51 \text { cases } & 90 \% & 53\end{array}$

SOURCE: Authors.

Bababekova et al. also reported that font size for reading text using a smart phone is $1.6 \mathrm{~mm}$ (7). Mean radial artery diameter is reported as $2.8 \mathrm{~mm}$ (interquartile range, $2.4-3.1 \mathrm{~mm}$ ) measured by ultrasound (8). When the image depth is set at $1.9 \mathrm{~cm}$ using the Edge II ultrasound equipment, a $2.8-\mathrm{mm}$ diameter radial artery showed a 6.6-mm diameter on a 4-inch display. These dimensions are adequate to identify a radial artery for puncture when compared to a font size for reading text.
Figure 3A. Experience with ultrasoundguided radial artery cannulation.

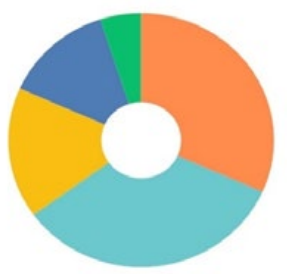

$\begin{array}{lrr}\text { None } & 5 \% & 3 \\ \text { Less than } 10 \text { cases } & 13 \% & 8 \\ 11 \sim 20 \text { cases } & 17 \% & 10 \\ 21 \sim 50 \text { cases } & 33 \% & 20 \\ \text { more than } 51 \text { cases } & 32 \% & 19 \\ \text { OURCE: Authors. } & & \end{array}$

Figure 4. Configuration that best facilitates ultrasound-guided radial artery puncture.

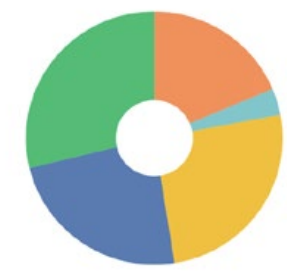

4 inch display fixed at

ultrasound probe

5.5 inch display fixed at

ultrasound probe

7.9 inch display put behind $\quad 25 \% \quad 15$

ultrasound probe

7.9 inch display put in front of $\quad 3 \% \quad 2$
ultrasound probe

9.7 inch display put behind

ultrasound probe

SOURCE: Authors.

Placing a large display close to the person who is going to perform the puncture makes it easier to identify the artery, but interferes with the puncture process. The 7.9-inch display may have been a parting of the ways in terms of preference for either legibility or obstacles to puncture.

This investigation has several limitations. First, the questionnaire was not administered after the anesthesiologists performed radial artery puncture using this system. Second, a change in resolution was required to show the image on the mobile device. This change might influence the identification of the radial artery. Third, the probe weight, which increased when the display was affixed, was not considered. This weight change may affect the probe operability. Also, the anesthesiologists were asked about their level of experience but not their age; thus, the influence of presbyopia cannot be determined. Lastly, the anesthesiologists all worked in the small area of Ibaraki Prefecture, Japan, and most received their training at the Tsukuba University anesthesiology program. This narrow range of respondents may have affected the results. Moreover, this is the first survey of anesthesiologists working in Ibaraki Prefecture, and the responses were given anonymously over the Internet; there was no information about the age group of anesthesiologists who failed to answer the survey, making it difficult to conduct a sensitivity analysis with little information to examine bias.

\section{CONCLUSION}

Among anesthesiologists, there is variation in the display size and distance from the operator's eye needed to facilitate ultrasoundguided radial artery puncture, as long as radial artery is well delineated. This results can be used as a reference for anesthesiologists when building a new system with in line positioning layout in the future.

\section{ACKNOWLEDGEMENTS}

\section{Author' contributions}

TH: Study planning, data collection, interpretation of results, data analysis, writing of the manuscript and approval thereof.

\section{Study assistance}

None declared. 


\section{Financial support and sponsorship}

None declared.

\section{Conflicts of interest}

None declared.

\section{Presentations}

None declared.

\section{Appreciations}

I would like to thank Editage (www.editage. com) for English language editing.

\section{REFERENCES}

1. Scheer BV, Perel A, Pfeiffer U. Clinical review: Complications and risk factors of peripheral arterial catheters used for haemodynamic monitoring in anaesthesia and intensive care medicine. Crit Care. 2002(6):198-204. doi: http://doi.org/10.1186/cc1489

2. White L, Halpin A, Turner M, Wallace L. UItrasound-guided radial artery cannulation in adult and paediatric populations: a systematic review and meta-analysis. $\mathrm{Br}]$ Anaesth. 2016(116):610-617. doi: http://doi.org/10.1093/ bja/aew097

3. Tsuchiya M, Mizutani K, Funai Y, Nakamoto T. In-line position of ultrasound images using wireless remote display system with tablet computer facilitates ultrasound-guided radial artery catheterization. ] Clin Monit Comput. 2016(30):101-106. doi: http://doi.org/10.1007/ s10877-015-9692-9

4. Ichino ], Kanayama H, Tano S, Hashiyama $T$. Effects of physical display size on text reading. J Image Inform TV Engnr. 2012(53):1570-1580.
5. Kubota S, Kishimoto K, Goshi S, Imai S, Igarashi Y, Matsumoto T, Haga S, Nakatsue T, Umano Y, Kobayashi Y. Preferred viewing distance for high definition television LCDs. ] Inform Process ]pn. 2012(53):1570-1580.

6. Nohara N, Matsui K, Setta M, Nohara T, Hara $\mathrm{N}$. Comparative study of visual distance while using mobile phones/smartphones and reading books. J of the Eye. 2015(32):163-165.

7. Bababekova Y, Rosenfield M, Hue JE, Haung RR. Font size and viewing distance of handheld smart phones. Optom Vis Sci. 2011(88):795-797. doi: http://doi.org/10.1097/ OPX.obo13e3182198792

8. Dharma S, Kedev S, Patel T, Rao SV, Bertrand OF, Gilchrist IC. Radial artery diameter does not correlate with body mass index: A duplex ultrasound analysis of 1706 patients undergoing trans-radial catheterization at three experimental radial centers. Int ] Cardiol. 2017(228):169-172. doi: https://doi.org/10.1016/j.ijcard.2016.11.145 